\title{
Professional, Critical, Policy, and Public Academics in Canada ${ }^{1}$
}

\author{
ROBERT J. BRYM \\ M. ReZa NAKhaIE
}

\begin{abstract}
This paper analyzes the results of a unique 2000 study of Canadian academics $(n=3,318)$, providing the first empirical assessment of Burawoy's intellectual types: professional, critical, policy, and public. After determining the distribution of academic types in the Canadian professoriate as a whole, the paper demonstrates that academic types fall along a left-right continuum; different fields of study contain different distributions of academic types; and public, policy, and critical academics tend to have different sociodemographic and economic characteristics than professional academics. The picture that emerges from the analysis is of a professoriate whose contours substantiate the broad outlines of Burawoy's typology.
\end{abstract}

Keywords: professors, intellectuals, universities

Résumé. Le présent article analyse les résultats d'une étude unique, faite en 2000, d'un échantillon représentatif d'universitaires canadiens ( $n=3$ 318) pour établir la première évaluation empirique des types intellectuels distingués par Burawoy: professionnel, critique, politique et public. Après avoir déterminé la distribution des types universitaires dans le professorat canadien en général, l'article démontre que ces types se distribuent sur une gamme de la gauche politique à la droite; que différentes disciplines offrent des distributions différentes de ces types; et que les universitaires publics, politiques et critiques tendent à avoir des traits socio-démographiques et économiques différents des universitaires professionnels. L'analyse révèle un professorat dont les contours confirment les grandes lignes de la typologie de Burawoy.

Mots-clés: professeurs; intellectuels; universités

1. We thank Rick Helmes-Hayes, Charles Kurzman, Neil McLaughlin, John Myles, and two anonymous CJS reviewers for helpful comments on a draft. 


\section{Normative vs. Theoretical Analysis}

I mitai Etzioni tells the story of an assistant professor of sociology I]at Columbia University in the late 1940s who published a movie review in a New York newspaper. Paul Lazarsfeld immediately called his young colleague onto the carpet. "Both Merton and I hope that this movie review you wrote is the last one." Under his breath he added, "The last thing we need is another C. Wright Mills" (Etzioni 2003:54).

Lazarsfeld, who earned a doctorate in applied mathematics from the University of Vienna, held scientific aspirations for sociology. In his view, popularizing the discipline, let alone politicizing it, stunted its growth as a science. His opinion did not stop him from working with the US State Department to identify opinion leaders in the Middle East, which may have helped the CIA overthrow the democratically elected Iranian government in 1953. However, Lazarsfeld's opinion did put him on a collision course with Mills. Mills saw the sociological imagination as an intellectual and ethical frame of mind that encourages the empirical analysis of society and the advancement of human freedom and reason, including opposition to colonialism and neocolonialism. Lazarsfeld did his best to discredit such views throughout the 1950s and until Mills' death in 1962. He declared White Collar a "very dumb book," branded The Sociological Imagination "ridiculous," and publicly denounced Mills when the opportunity to do so arose. In 1961, he conspired with Talcott Parsons and Seymour Martin Lipset to have the International Sociological Association retract its invitation to Mills to give a keynote address at the 1962 ISA meetings in Washington, DC. For his part, Mills gave as good as he got. He declared "abstracted empiricism" intellectually bankrupt, writing that Lazarsfeld might perfect research methods but could not produce ideas. Practitioners of abstracted empiricism, Mills concluded, were doomed to become state functionaries and corporate drones, abandoning thinking for measurement. Mills was hardly predisposed to Lazarsfeld's mindset, having failed his statistics exams at both the undergraduate and graduate levels (Summers 2006).

Even if the details of the Lazarsfeld-Mills feud are news to some readers, the broad outlines of the dispute will undoubtedly have a familiar ring. As with the performances of Christmas mummers in 19th century rural Newfoundland, the dramatis personae change over time, but the structure of the conflict that animates the play remains much the same from one season to the next. Intellectual upstarts proclaim that the professionals have only interpreted the world in various ways; the point is to change it. The professionals note how social and political motives inevitably bias research and delegitimize the discipline in the eyes of the 
public. The upstarts unearth evidence of the professionals themselves putting sociology to political use. The rhetorical winds cause the flames to gutter and then extinguish. The great questions, though engaged, remain unanswered. Exit ghosts. Enter the new generation for the next performance.

Normative questions about appropriate extra-disciplinary and disciplinary roles do not concern sociologists alone. They extend to all intellectuals. Almost every decade witnesses the publication of a synthetic overview of the sociology of intellectuals in which the author laments the failure of the field to advance much beyond prescriptive arguments about what intellectuals ought to do, and argues, largely in vain, for improved theoretical and empirical analyses of the social bases of intellectual life (e.g., Brym 1980; 2001; Karabel 1996; Kurzman and Owens 2002). Bigger stage. Same play.

Burawoy's recent intervention combines normative and theoretical elements (Burawoy 2005a). His theoretical advance is typological, identifying a fourfold intellectual division of labour among sociologists. Professional sociologists engage in programs of scholarly research that generate instrumental knowledge intended for an academic audience. Critical sociologists engage in programs of scholarly research that generate "reflexive" knowledge intended to influence the actions of an academic audience. Policy sociologists produce instrumental knowledge defined narrowly by the needs of clients. Public sociologists produce reflexive knowledge intended to influence the actions of a broad extraacademic audience. Individual sociologists may specialize in one or another role over the course of their careers or they may focus on different roles at different career stages. However, according to Burawoy, each sociological role benefits from the vitality of the others; a healthy discipline requires a balance among the four.

Just what that balance should be is, of course, a normative issue. Burawoy advocates a more public sociology. Although we are sympathetic to his position, our aim in this paper is not to argue that more sociologists should speak in a clearer voice to a broad audience about the life or death issues of the day (cf. Brym 2008). As McLaughlin and Turcotte (2007) recently noted, most of the spirited debate that followed the publication of Burawoy's 2004 American Sociological Association presidential address focused on the normative rather than the theoretical issues he raises. Burawoy is thus threatened with the same fate as earlier interventions. We do not want to help swamp his useful theoretical contribution.

To the contrary, our aim in this paper is to assist McLaughlin and Turcotte in their rearguard action to give Burawoy's argument empirical 
substance. Our data come from Nakhaie's 2000 survey of The Academic Profession in Canada. After operationalizing Burawoy's four academic types and determining their distribution among the Canadian professoriate, we examine how members of each type are arrayed along five ideological dimensions. We find that the four academic types fall along a distinct left-right continuum. We then examine differences in the distribution of academic types among fields of study. The picture that emerges from our analysis is of a complex and highly differentiated professoriate whose contours substantiate the broad outlines of Burawoy's typology.

\section{DATA}

Nakhaie's survey of The Academic Profession in Canada included questions on sociodemographics, socioeconomic background, political orientation, and attitudes towards gender and ethnic inequality. Sampling involved systematic selection of 10,000 full-time faculty members within 12 strata based on the province and size of the university. The response rate was 34 percent $(n=3,318)$, which is at the high end for surveys of academics involving self-administered questionnaires (Neuman 2006:295-6). We nonetheless tested for representativeness, and were encouraged to find that the distribution of the sample and the academic population by field, rank, and gender were almost identical; chi-square tests revealed no difference between sample and population. We also examined visible minority data submitted by universities to the Federal Contractors Program. They show that the percentage of visible minority group members in the academic community is almost the same as in our sample (Kobayashi 2002; Nakhaie 2007). ${ }^{2}$

\section{Operationalizing the Typology}

The first task we set ourselves was to operationalize Burawoy's typology. The survey of The Academic Profession in Canada was not formulated

2. A basic weight was first created equal to the inverse of the probability of selection for each sample record: $\mathrm{WT}=1 / \mathrm{f}=\mathrm{Nij} / \mathrm{nij}$, where $\mathrm{Nij}=$ the total population of academics in region $\mathrm{i}$ and university size stratum $\mathrm{j}$, nij=the sample population of academics in region $\mathrm{i}$ and university size stratum $\mathrm{j}$, and $\mathrm{f}=$ the sampling fraction. Statistical weights of the responding academics were then adjusted by uniformly distributing among them the statistical weights of nonrespondents, based on the assumption that the two groups are similar in the characteristics of interest: $\mathrm{NRCF}=\mathrm{nij} / \mathrm{rij}$, where $\mathrm{NRCF}=$ the nonresponse correction factor, and rij=the number of responding academics in region i and university size strata j. Finally, population weight (POPWT) was calculated: POPWT $=$ WT $*$ NRCF, and then a sample weight (SAMWT) was applied to the analyses: SAMWT=POPWT/mean of POPWT (cf. Lennards 1990). Separate analysis using unweighted data produced substantially similar results. 
with Burawoy's typology in mind. Our operationalization is therefore constrained by the nature of the data at hand. We believe that the survey allows a crude but acceptable operationalization, based largely on two successful tests of its validity, which we report below, but acknowledge that our operationalization is less than ideal. We look forward to a survey designed specifically to measure, elaborate, and test the validity of Burawoy's typology.

Burawoy first distinguishes academic types by the audiences they address. Professional and critical sociologists present their knowledge to colleagues mainly in the form of refereed journal articles. As Burawoy emphasizes, "professional sociology is accountable to peer review" and its main concern is "to develop a monopoly of abstract, specialized knowledge evaluated by peers ... in journals regulated by professional gatekeepers" (Burawoy 2005a:16; 2005b:74). Critical sociology is also oriented toward the publication of peer-reviewed articles but it acts as the "conscience" of professional sociology (Burawoy 2005a:10). In contrast, public and policy sociologists are more interested in presenting knowledge to extra-academic audiences: the general public in the case of public sociologists, and clients interested in practical knowledge in the case of policy sociologists. Such clients and the general public are relatively unlikely to read peer-reviewed journal articles because they tend to lack the training and interest to do so. Accordingly, we infer that public and policy sociologists are more likely to write books and reports, and less likely to write refereed journal articles, than professional and critical sociologists are. This understanding is also emphasized by McLaughlin, Kowalchuk, and Turcotte (2005:141), who write that "public sociology is often written for a book or magazine audience."

Of course, norms regarding book and report versus refereed article writing vary from one discipline or type of discipline to the next. For example, it has been demonstrated for both Canada and the United States that natural science professors are less likely to write books and reports, and more likely to write refereed journal articles, than are liberal arts professors (Clemens et al. 1995; Nakhaie 2002). ${ }^{3}$ Still, we believe that public and policy intellectuals are more likely to write books and reports than are professional and critical intellectuals in all fields, including the natural sciences. The career of Canadian geneticist and public intellectual David Suzuki illustrates the point. For 15 years after completing his $\mathrm{PhD}$ in zoology at the University of Chicago in 1961, Suzuki published only scientific articles and papers. He first became involved in broadcast-

3. Intradisciplinary variations are evident too. For example, Wolfe (1990) shows that, in American sociology, the tendency to favour articles over books varies by the size and geographical location of Departments of Sociology. 
ing in 1970, but his career as a public intellectual took off in 1979, when he started hosting the CBC TV series, The Nature of Things, eventually broadcast in nearly 50 countries. By 1985, after publishing more than 170 scientific articles and papers, Suzuki's transformation from professional to public intellectual was complete. He published no scientific papers or articles after that date. However, he published his first book in 1976, his second in 1986, and about 40 more books (many of them for children) thereafter (Suzuki, n.d.). Suzuki's case illustrates that, even within the natural sciences, the shift from professional to public intellectual typically means fewer refereed articles and more books.

Applying the distinction just outlined to the entire professoriate, we operationalized the knowledge dimension of Burawoy's typology as the ratio of the number of refereed articles to books and reports written by each respondent. The breakpoint on the knowledge dimension is the median of the ratio of refereed articles to books and reports.

We emphasize three qualifications:

1. Our association of refereed article writing with professional and critical academics, and book and report writing with public and policy academics, is historically specific. That is, we believe that the emphasis on writing peer-reviewed articles as opposed to books among professional and critical academics has grown over time. First evident among natural scientists more than a century ago, the trend is now well entrenched among social scientists and is making inroads in the humanities. If our data came from 1950 rather than 2000 , or if we surveyed elderly academics only, we would expect to find a weaker tendency for professional and critical academics to focus on writing peer-reviewed journal articles.

2. Our association of peer-reviewed article writing with professional and critical academics, and book and report writing with public and policy academics, is a matter of degree, not kind. We acknowledge that professional and critical academics write books and reports, and that public and policy academics write peer-reviewed articles. We contend merely that the ratio of one type of publication to the other varies in predictable ways among these academic types.

3. Writing books and reports versus peer-reviewed articles is by no means the only difference between professional and critical sociologists, on the one hand, and public and policy sociologists, on the other. However, it is a difference that Burawoy identifies and one that has predictive validity, as we will see.

The second dimension of Burawoy's typology concerns reflexivity. This dimension, like the first, is ill-defined by Burawoy (Acker 2005; 
McLaughlin and Turcotte 2007). McLaughlin, Kowalchuk, and Turcotte (2005) express justifiable concern that analysts often use "reflexivity" synonymously with radicalism or leftism, thus leaving the term without a distinct meaning. Mindful of this ambiguity, we relied on Burawoy's point that reflexivity refers to the normative relationship between academics and society. It deals with dialogue about "the direction of society" (Burawoy 2005a:11). Accordingly, we operationalized the reflexivity dimension using a question asking respondents if they believe that "universities have a major obligation to help society solve its problems." We believe that respondents would not strongly agree that universities are so obliged if they take an ivory-tower view of the university - regarding it as an institution removed from mundane social concerns, and focused on purely intellectual issues - and distinguish respondents who strongly agree that universities have a major obligation to help society solve its problems from others. Our operationalization implies that belief in whether universities have a major obligation to solve social problems is orthogonal to political orientation and may in principle be associated with any political orientation. As Burawoy (2005a:8) emphasizes,

public sociology has no intrinsic normative valence, other than the commitment to dialogue around issues raised in and by sociology. It can as well support Christian Fundamentalism as it can Liberation Sociology or Communitarianism.

Crosstabulating the reflexivity and audience dimensions gives us the percentage of Canadian academics who fall into each of Burawoy's four academic categories (Table 1). Public intellectuals account for almost two out of ten Canadian academics, professionals for more than three out of ten. Policy and critical intellectuals each account for nearly a quarter of the total.

\section{Validating the Operationalization}

As noted, Burawoy does not provide clear directions for operationalizing his academic types. We nonetheless believe that our operational-

Table 1. Academic Types, Canada ( $n=2,706$; percent in parentheses)

\begin{tabular}{|l|l|l|}
\hline \multicolumn{1}{|c|}{ Audience } & \multicolumn{1}{|c|}{ Academic $^{l}$} & \multicolumn{1}{c|}{ Nonacademic $^{2}$} \\
\hline \multicolumn{1}{|c|}{ Type of knowledge } & & \\
\hline Instrumental $^{3}$ & Professional (31.7) & Policy (24.0) \\
\hline Reflexive $^{4}$ & Critical (24.8) & Public (19.4) \\
\hline
\end{tabular}

1 Ratio of refereed journal articles to (books + reports) median or greater.

2 Ratio of refereed journal articles to (books + reports) below the median.

3 Somewhat agree/somewhat disagree/strongly disagree that universities have a major obligation to help society solve its problems.

4 Strongly agree that universities have a major obligation to help society solve its problems. 
ization is consistent with his conceptualization and has face validity. To increase confidence that we are measuring what Burawoy intended, we examined aspects of our operationalization's predictive validity. For example, Burawoy emphasizes that professional sociologists tend do more research and secure more research funding than public sociologists do. In his words, "the strength of professional sociology is concentrated in research departments" (Burawoy 2005a:19; 2005b:75). Burawoy also implies that professional intellectuals teach less than public intellectuals. He thus writes that students are "the first," "most immediate," and "captive" public of the public sociologist (Burawoy 2005b:79; 2005a:7; Brym 2009), and "as teachers we are all potentially public sociologists" (Burawoy 2005a:9). Our data support Burawoy's claims. On average, public academics in our sample taught 13.7 hours a week, conducted research 11.9 hours a week, and secured about $\$ 297,000$ in research funds over the course of their careers to date. By comparison, professional academics taught 2.3 hours a week less than public intellectuals, conducted research 6.8 hours a week more, and secured $\$ 621,000$ more in research funds. ${ }^{4}$

A second set of predictive validations concerns academics' ideological orientations. It follows from Burawoy's discussion that, on average, public and critical sociologists stand to the left of the mean for all sociologists; professional sociologists stand to the right; and policy sociologists stand in between. True, Burawoy writes that, in principle, "public sociology has no intrinsic normative valence"(2005a:8). In practice, however, the public sociologists he mentions - Dorothy Smith, Patricia Hill Collins, W.E.B. Du Bois, C. Wright Mills - all lean to the left. So does Burawoy himself, as is evident, for example, in his strong public opposition to the war in Iraq. In general, although reflexivity does not necessarily imply leftism, scholars who use the term typically associate it with the left (Lynch 2000; Burawoy 2005c; 2005d).

Our data speak clearly to the issue of academics' ideological orientations. The survey of The Academic Profession in Canada included 17 questions concerning support for unions ( 3 items), union militancy (4 items), economic equality (4 items), gender equality ( 3 items), and racial/ethnic equality ( 3 items). ${ }^{5}$ Permitted responses formed four-response Likert scales. Factor analysis employing varimax rotation resulted in the

4. Additionally, one of our survey questions asked respondents to list written contributions other than articles, books, and reports. Among the 21 respondents who listed administrative and evaluation reports as "other" outputs, 13 were policy academics and 5 were public academics. Among the 24 respondents who listed newspaper, magazine, and TV contributions as "other" outputs, 11 were public academics and 6 professional academics.

5. The questionnaire is available on request from the authors. 
five factors arrayed along the horizontal in Table 2, which reports deviations from the mean for each academic type on all five ideological dimensions. To see if the four academic types meaningfully differ from each other, we used scores for public intellectuals as a baseline and calculated whether the 15 other scores in Table 2 were statistically significant from the scores for public intellectuals. In fourteen cases, they were; in the fifteenth case, the score was at least in the expected direction.

\section{Table 2. Academic Type by Ideological Dimension (Deviations from the} Mean)

$\begin{array}{lcccccc}\begin{array}{c}\text { Ideological } \\ \text { dimension } \\ \text { Academic type }\end{array} & \begin{array}{c}\text { Union } \\ \text { support }\end{array} & \begin{array}{c}\text { Economic } \\ \text { equality }\end{array} & \text { Militancy } & \begin{array}{c}\text { Racial } \\ \text { equality }\end{array} & \begin{array}{c}\text { Gender } \\ \text { equality }\end{array} & \begin{array}{c}\text { Mean } \\ n^{l}\end{array} \\ \text { Public } & 1.20 & 1.49 & 1.42 & 0.93 & 0.52 & 526 \\ \text { Critical } & 0.27^{*} & 0.73^{*} & 0.46^{*} & 0.45^{*} & 0.23 & 672 \\ \text { Policy } & 0.23^{*} & 0.03^{*} & -0.04^{*} & -0.10^{*} & -0.09^{*} & 651 \\ \text { Professional } & -0.35^{*} & -0.89^{*} & -0.61^{*} & -0.57^{*} & -0.43^{*} & 858 \\ \text { Mean } & 9.43 & 11.53 & 11.27 & 7.83 & 10.15 & \\ \text { Std. dev. } & 3.00 & 3.43 & 3.23 & 2.63 & 1.81 & \\ \mathrm{n} & 2,725 & 2,696 & 2,726 & 2,693 & 2,693 & 2,706 \\ * & \text { p <.05 (probability of category mean differing from the mean for public academics) } \\ 1 & \text { The n's vary by dependent variable }\end{array}$

Table 2 also shows that public academics are most likely to be on the left of the ideological spectrum, followed by critical academics, policy academics, and professional academics in that order. Public academics' deviations from the ideological means tend to be greater with respect to class-related issues (support for economic equality, unions, and union militancy) than for gender and racial/ethnic issues (support for gender and racial/ethnic equality).

To further demonstrate the validity of our operationalization, we summed the category values for each factor and created new indices so that high scores indicate strong support for unions, militancy, economic equality, gender equality, and racial/ethnic equality. We excluded missing cases on these variables, but computed indices as long as the respondent answered at least one of the questions. A second-order factor analysis confirmed the unidimensionality of the five indices. Therefore, we summed them into a single index, which we label "leftism." To see if the typology of academic types developed above can predict variation in leftism, we regressed academic types against leftism, with the professional type as the reference category, and controlled for the effects of region, gender, age, marital status, ethno-racial origin, religiosity, income, and rank. The unstandardized coefficients were 7.15 for public academics $(\mathrm{p}<.001), 4.72$ for critical academics $4.72(\mathrm{p}<.001)$ and 1.48 
for policy academics $(\mathrm{p}<.005)$. The differences between each of these coefficients of leftism and the ideological orientation of the professional academic type are statistically significant and in the direction suggested by Burawoy. We conclude that, in addition to whatever face validity inheres in our operationalization, it also enjoys considerable predictive validity insofar as it jibes with the teaching and research division of labour, and the ideological predispositions that, according to Burawoy, are associated with his four academic types.

\section{Interdisciplinary Differences}

Burawoy's focus on sociology does not allow us to view how the mix of academic types varies by discipline. Therefore, we set ourselves the task of extending his analysis by considering interdisciplinary differences in the prevalence of academic types. Figure 1 shows the distribution of academic types by disciplinary category. As a crude measure of leftism, we may subtract the percentage of public academics from the percentage of professional academics in each disciplinary category. Sociology clearly falls to the left with a leftism score of -16 . Only education, with a score of -25 , lies farther to the left. Moving to the right of sociology, we find the humanities with a leftism score of -11 , and then the only surprise in the array: social scientists other than sociologists, with a leftism score of +5 , stand to the right of business professors, with a leftism score of 0 . Unremarkably in the light of previous research, natural scientists and mathematicians $(+22)$, and professors in the medical sciences $(+26)$ are the most right-leaning professors in Canada.

In view of Burawoy's call for balance among the four academic types, it is interesting to note that sociology has achieved better-thanaverage numerical balance compared to other disciplinary categories. Assume that perfect balance involves an equal distribution of the four academic types within each category: 25 percent of each type. Within each disciplinary category, take the absolute value of the difference between 25 percent and the percentage of each academic type. Now add the 4 absolute values in each disciplinary category. A sum of 0 would indicate perfect numerical balance; the higher the sum, the greater the numerical imbalance. Figure 1 shows that the most numerically balanced disciplinary category is the social sciences other than sociology, with a sum of 8 . Next is business, with a sum of 20. For sociology, the sum is 24 , followed by education (32), natural sciences and mathematics (38), the humanities (44), and medical sciences (48). Numerical balance is of course not the same as intellectual balance. Different norms concerning intellectually appropriate balance govern each disciplinary category. 


\section{Figure 1. Academic Types within Fields}
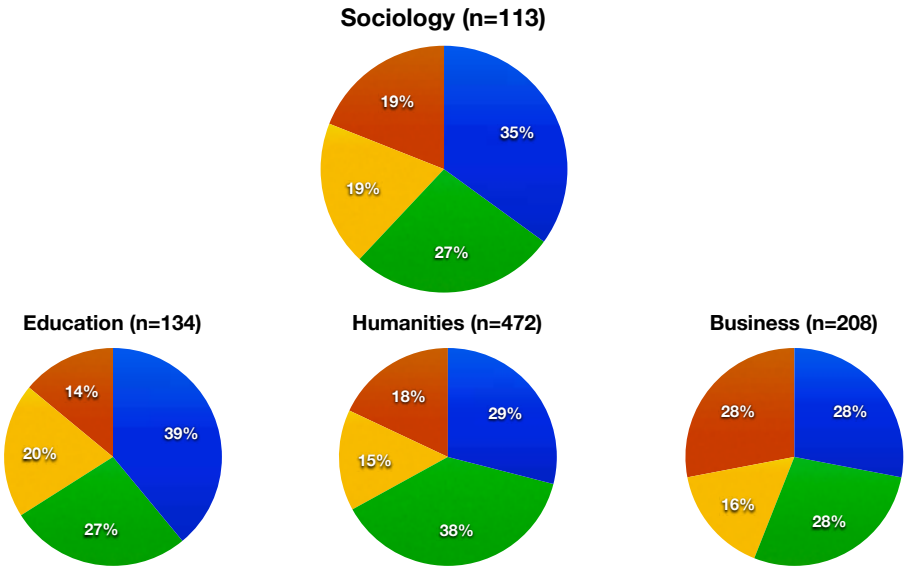

Other Social Sciences $(n=307)$ Natural Sciences and Math $(n=711)$

Medical Sciences $(n=648)$
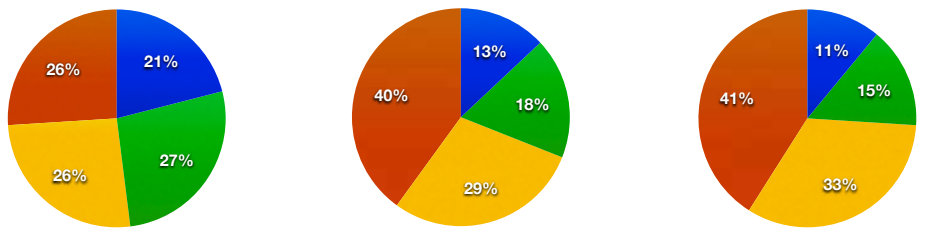

Public Policy Critical Professional

However, academics often contest these norms, and it is useful to be able to engage in such debates having in mind an empirically grounded picture of the distribution of academic types, such as the one we have provided here.

\section{Academic Type Differentiation}

Burawoy is mute on the question of whether academic types tend to differ in terms of their social characteristics. Yet the literature hints at this possibility. We know, for example, that academics' political orientations and social attitudes are associated with their sociodemographic background (Nakhaie and Brym 1999). Since, as we have seen, academic types may also be arrayed on a left-right continuum, we may reasonably expect that different clusters of social characteristics distinguish professional, public, policy, and critical academics.

Table 3 offers a preliminary sketch of the social differentiation of Canadian academic types. It shows differences in the log of the odds of being a public, policy, or critical academic compared to being a professional academic. Since the log of the odds has little intuitive meaning, 
we also show exponentiated coefficients. The exponent of a coefficient is the factor by which the log of the odds must be multiplied to achieve a single unit of change in a predictor variable. For interval and ratio variables, one must exponentiate the coefficient and then take it to the power of the desired category.

In brief, Table 3 shows that Canadian academic types do not differ by visible minority status, ethnicity, or religiosity. However, public and policy academics are more likely to be female, young, unmarried, employed in institutions of low academic standing, ${ }^{6}$ and earn relatively low income than are professional academics. This means that professional academics tend to enjoy higher status on a range of sociodemographic and economic variables than public and policy academics do. Additionally - and surprisingly - we note that public, policy, and critical academics are less likely to be employed in Quebec universities than are professional academics. This finding contradicts the view (based on analyses lacking controls) that public academics are more likely to be employed in Quebec than elsewhere in Canada (Brym and Myles 1989).

Table 3. Multinomial Logit Analysis of Academic Types

\begin{tabular}{|c|c|c|c|c|c|c|}
\hline & \multicolumn{2}{|c|}{ Public } & \multicolumn{2}{|c|}{ Policy } & \multicolumn{2}{|c|}{ Critical } \\
\hline & $B$ & $\operatorname{Exp}(B)$ & $B$ & $\operatorname{Exp}(B)$ & $B$ & $\operatorname{Exp}(B)$ \\
\hline Intercept & 13.241*** & & $21.242 * * *$ & & -4.102 & \\
\hline Atlantic & 0.114 & 1.121 & 0.069 & 1.071 & 0.007 & 1.007 \\
\hline Quebec & -0.632 & $0.531 * * *$ & -0.400 & $0.670^{*}$ & -0.685 & $0.504 * * *$ \\
\hline West & 0.280 & 1.323 & -0.041 & \begin{tabular}{|l|}
0.960 \\
\end{tabular} & 0.197 & 1.218 \\
\hline $\mathrm{BC}$ & -0.170 & 0.844 & 0.048 & 1.049 & 0.145 & 1.156 \\
\hline Age & -0.017 & $0.983 *$ & -0.029 & $0.971 * * *$ & -0.003 & 0.997 \\
\hline Male & -0.527 & $0.590 * * *$ & -0.453 & $0.636^{* * *}$ & -0.046 & 0.955 \\
\hline Married & -0.274 & $0.760 *$ & -0.268 & \begin{tabular}{|l|}
$0.765^{*}$ \\
\end{tabular} & 0.130 & 1.139 \\
\hline Visible minority & 0.275 & 1.316 & -0.161 & 0.851 & 0.010 & 1.010 \\
\hline Jewish & -0.068 & 0.935 & -0.026 & 0.974 & -0.044 & 0.957 \\
\hline French & -0.01 & 0.984 & 0.174 & 1.190 & -0.058 & 0.944 \\
\hline Canadian & 0.123 & 1.131 & 0.047 & 1.048 & 0.005 & 1.005 \\
\hline European & -0.011 & 0.989 & -0.085 & 0.919 & -0.004 & 0.996 \\
\hline \begin{tabular}{|l|} 
Religiosity \\
\end{tabular} & 0.001 & 1.001 & -0.011 & \begin{tabular}{|l|}
0.989 \\
\end{tabular} & -0.130 & 0.878 \\
\hline Log of income & -0.893 & $0.409 * * *$ & -1.650 & $0.192 * * *$ & 0.421 & 1.523 \\
\hline Institutional rank & -0.639 & $0.528 * * *$ & -0.279 & \begin{tabular}{|l|}
$0.757 *$ \\
\end{tabular} & -0.110 & 0.896 \\
\hline Final model $\chi^{2}$ & $283.2 * * *$ & & & & & \\
\hline DF & 48 & & & & & \\
\hline Nagelkerke pseudo- $\mathrm{R}^{2}$ & 0.114 & & & & & \\
\hline
\end{tabular}

6. We measured institutional standing using Gourman's (1997) 5-point scale of Canadian universities, the only such scale available. The better-known Maclean's magazine ranking scales universities within categories - medical/doctoral, comprehensive, and primarily undergraduate institutions - but does not provide one scale for all institutions. 


\section{Conclusion}

Normative arguments have long dominated the sociological study of intellectuals to the detriment of theoretically driven empirical analyses, and even analyses of the latter type have tended to be based on anecdotal evidence. In this paper we have sought to move the discussion in a different direction. Using existing survey data, we operationalized Burawoy's academic typology and presented two successful tests of its predictive validity. Thus equipped, we calculated the percentage of Canadian academics, and academics within clusters of cognate disciplines that fall into each of Burawoy's four academic categories. We then showed that the categories may be arrayed on a left-right spectrum and that public, policy, and critical academics differ from professional academics in terms of certain sociodemographic and economic characteristics. The result is a first rudimentary sociological map of the Canadian professoriate. Maps are useful if they lead us to interesting places, and we have offered ours in the hope that it will provoke interest in the development of a metric advancing theoretically motivated and empirically grounded analyses of the character and consequences of intellectual life in Canada and elsewhere.

\section{REFERENCES}

Acker, Joan. 2005. Comments on Burawoy on public sociology. Critical Sociology $31: 321-331$.

Brym, Robert J. 1980. Intellectuals and Politics. London: Allen and Unwin. 2001. Intellectuals, sociology of. Pp. 7631-5 in Neil Smelser and Paul Baltes, eds., International Encyclopedia of the Social and Behavioral Sciences. Oxford: Elsevier Science. 2008. Sociology as a Life or Death Issue. Toronto: Nelson. 2009 Why I teach intro. Academic Matters: The Journal of Higher Education 4(1) http://www.academicmatters.ca/current issue.article. gk? catalog item id=2079\&category $=$ featured articles Accessed July 30,2009 .

Brym, Robert J. and John Myles. 1989. Social science intellectuals and public issues in English Canada. University of Toronto Quarterly 58(4):442-51.

Burawoy, Michael. 2005a. For public sociology. American Sociological Review 70:4-28.

2005b. The return of the repressed: Recovering the public face of U.S. sociology, one hundred years on. Annals of the American Academy of Political and Social Science 600:68-85.

2005c. The critical turn to public sociology. Critical Sociology 31:313326. 
2005d. Rejoinder: Towards a critical public sociology. Critical Sociology 31(3):379-390.

Clemens, Elisabeth S., Walter W. Powell, Kris McIlwane, and Dina Okamoto. 1995. Careers in print: Books, journals, and scholarly reputations. American Journal of Sociology 101:433-94.

Etzioni, Amitai. 2003. My Brother's Keeper: A Memoir and a Message. Lanham MD: Rowman \& Littlefield.

Gourman, Jack. 1997. The Gourman Report: Undergraduate Programs, 10th ed. New York: Princeton Review.

Karabel, Jerome. 1996. Towards a theory of intellectuals and politics. Theory and Society 25:205-33.

Kobayashi, A. 2002. Now you see them, how you see them: Women of colour in Canadian academia. Pp. 44-54 in S. Heald, ed., Ivory Towers, Feminist Issues: Selected Papers from the WIN Symposia, 2000-2001. Ottawa: Humanities and Social Sciences Federation of Canada.

Kurzman, Charles and Lynn Owens. 2002. The sociology of intellectuals. Annual Review of Sociology 28:63-90.

Lynch, M. 2000. Against reflexivity as an academic virtue and source of privileged knowledge. Theory, Culture and Society 17(3):26-54.

Lennards, Jos. 1990. The academic profession in Canada. Working paper, Department of Sociology, Glendon College, York University.

McLaughlin, Neil, Lisa Kowalchuk, and Kerry Turcotte. 2005. Why sociology does not need to be saved: Analytic reflections on public sociologies. The American Sociologist 36(3/4):133-51.

McLaughlin, Neil and Kerry Turcotte. 2007. The trouble with Burawoy: An analytic, synthetic alternative. Sociology 41:813-28.

Nakhaie, M. Reza. 2002. Gender differences in publication among university professors in Canada. Canadian Review of Sociology and Anthropology 39:151-80.

2007. Universalism, ascription and academic rank: Canadian professors, 1987-2000. Canadian Review of Sociology and Anthropology 44:36186.

Nakhaie, M. Reza and Robert J. Brym. 1999. The political attitudes of Canadian professors. Canadian Journal of Sociology 24:329-53. www.ualberta. ca/ cjscopy/articles/nakhaie.html (accessed September 24, 2008).

Neuman, L. 2006. Social Research Methods: Qualitative and Quantitative Approaches. New York: Pearson.

Summers, John H. 2006. Perpetual revelations: C. Wright Mills and Paul Lazarsfeld. Annals of the American Academy of Political and Social Science 608:25-40. 
Suzuki, David. n.d. Dr. David Suzuki: Detailed CV. http://www.davidsuzuki.org/ files/general/drsuzukicv.pdf (accessed September 24, 2008).

Wolfe, Alan. 1990. Books vs. articles: Two ways of publishing sociology. Sociological Forum 5:477-89.

Robert J. Brym, FRSC, is a Professor of Sociology at the University of Toronto. His work has recently appeared in Social Forces, Political Science Quarterly and Studies in Conflict and Terrorism. He has published numerous works on intellectuals. His Intellectuals and Politics will be reissued by Routledge in 2009. rbrym@chass.utoronto.ca

Reza Nakhaie is a Professor of Sociology at University of Windsor. His research interests centre around issues of diversity, equity and justice, and cultural and political forces that produce and reproduce inequality. His recent publications have appeared in Canadian Review of Sociology, Canadian Journal of Sociology, Canadian Ethnic Studies, Canadian Journal of Political Sciences, Review of Radical Political Economics, International Journal of Migration and Integration, International Journal of Law and Psychiatry, Journal of School Violence, Journal of Family and Economic Issues and Journal of Ethnic and Migration Studies. He is currently the editor of the Canadian Review of Sociology. nakhaie@uwindsor.ca 
